\title{
Suppressing Hydrogen Sulfide Generation by Nitrate or Oxygen Addition in Column Percolation Experiment
}

\author{
Shumpei Kitazaki ${ }^{1}$, Kei Nakagawa ${ }^{1}$, Tomonori Kindaichi ${ }^{2}$, Hiroshi Asakura, ${ }^{1}$ * \\ ${ }^{1}$ Graduate School of Fisheries Science and Environmental Studies, Nagasaki University, Nagasaki, Japan \\ ${ }^{2}$ Graduate School of Engineering, Hiroshima University, Hiroshima University, Higashihiroshima, Japan
}

Email address:

asakura_hiroshi@yahoo.co.jp (H. Asakura)

\section{To cite this article:}

Shumpei Kitazaki, Kei Nakagawa, Tomonori Kindaichi, Hiroshi Asakura. Suppressing Hydrogen Sulfide Generation by Nitrate or Oxygen Addition in Column Percolation Experiment. American Journal of Environmental Protection. Vol. 4, No. 1, 2015 , pp. 55-61.

doi: 10.11648/j.ajep.20150401.18

\begin{abstract}
H}_{2} \mathrm{~S}$ generation suppression by the addition of $\mathrm{NO}_{3}$ from reagent (NR) or compost (NC), and $\mathrm{O}_{2}$ supply (OX) was quantitatively estimated in column percolation experiments. The cumulative amounts of oxygen added exceeded 300 mmol-O/L in NR and NC, and approximately $2 \mathrm{mmol}-\mathrm{O} / \mathrm{L}$ in $\mathrm{OX}$ on day 75 . The cumulative amounts of $\mathrm{H}_{2} \mathrm{~S}$ generated on day 60 in control, NR, NC, and OX were $69,26,71$, and $31 \mathrm{mmol}-\mathrm{H}_{2} \mathrm{~S} / \mathrm{L}$, respectively. The amounts in NR and OX were half of that in control, whereas the amount in $\mathrm{NC}$ was almost the same as that in control. The $\mathrm{H}_{2} \mathrm{~S}$ generation rates from day 50 to day

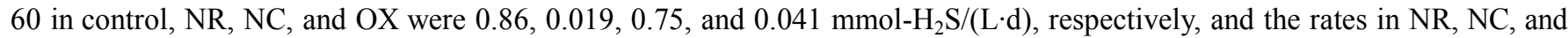
$\mathrm{OX}$ were $0.02,0.9$, and 0.05 times that in control. In this way, the $\mathrm{H}_{2} \mathrm{~S}$ generation suppression effects of $\mathrm{NO}_{3}$ reagent addition were observed. In NR, although $\mathrm{NO}_{3}$ was injected from the top of the column, the suppression effect reached the deep layer.
\end{abstract}

Keywords: Landfill Site, Waste Gypsum Board, Hydrogen Sulfide, Generation Suppression, Nitrate

\section{Introduction}

Hydrogen sulfide $\left(\mathrm{H}_{2} \mathrm{~S}\right)$ gas is generated at landfill sites globally [1-6]. The inhalation of $\mathrm{H}_{2} \mathrm{~S}$ gas at $750-1000 \mathrm{ppm}$ causes abrupt physical collapse [7] (hereafter, $\mathrm{H}_{2} \mathrm{~S}$ exceeding $1000 \mathrm{ppm}$ is called $\mathrm{H}_{2} \mathrm{~S}_{\text {high }}$ ). In 1999 , three workers at an inert solid waste landfill site (a type of landfill site in Japan where waste plastic, rubber, metal, glass, ceramic, and construction and demolition debris are acceptable, as well as waste gypsum board without protective paper sheet at the time of the accident No gas venting pipes are required.) died of exposure to 15000 ppm $\mathrm{H}_{2} \mathrm{~S}$ gas. $\mathrm{H}_{2} \mathrm{~S}$ gas is produced at a landfill when sulfate-reducing bacteria (SRB) consume organic matter and convert sulfate $\left(\mathrm{SO}_{4}\right)$ under anaerobic conditions $[1,8,9]$. The source of $\mathrm{SO}_{4}$ in construction and demolition debris is predominantly gypsum $\left(\mathrm{CaSO}_{4}\right)$ [10]. Suggested measures for preventing $\mathrm{H}_{2} \mathrm{~S}$ generation or diffusion at a landfill site include the exclusion of anaerobic conditions (by water exclusion and/or oxygen $\left(\mathrm{O}_{2}\right)$ supply) [11], and the trapping of generated $\mathrm{H}_{2} \mathrm{~S}$ gas (by conversion into iron sulfide using iron-containing material [12,13], and by adsorption to activated carbon [14] or zeolite [15]). The Ministry of the Environment in Japan recommended the appropriate installation of cover soil (to prevent rainwater percolation and trap generated $\mathrm{H}_{2} \mathrm{~S}$ gas by iron in soil) and the use of gas venting pipes $\left(\mathrm{O}_{2}\right.$ supply). However, in regard to the gas venting pipe, a large cost is necessary for the installation and the identification of $\mathrm{H}_{2} \mathrm{~S}$ generation spots as the installation points. In addition, oxygen supply to the waste layer via gas venting pipes is not possible at coastal landfill sites because a major portion of the waste layer is found below the surface of inner leachate. It is also a fact that trapping by iron does not prevent $\mathrm{H}_{2} \mathrm{~S}$ generation per se. Therefore, it is necessary to develop a method to suppress $\mathrm{H}_{2} \mathrm{~S}$ generation.

In sewage systems, $\mathrm{H}_{2} \mathrm{~S}$ generation suppression by nitrate $\left(\mathrm{NO}_{3}\right)$ addition has been reported [16, 17]. This has been attributed to the increase in the oxidation-reduction potential (ORP) caused by the presence of $\mathrm{NO}_{3}$. As the Gibbs free energies of the oxidation of organic matter $\left(\mathrm{CH}_{2} \mathrm{O}\right)$ with dissolved $\mathrm{O}_{2}, \mathrm{NO}_{3}$, and sulfate $\left(\mathrm{SO}_{4}\right)$ as the electron acceptor are $-125,-119$, and $-25.4 \mathrm{~kJ} / \mathrm{mol}$ [18], respectively, the reaction is said to occur in the order of respiration by aerobic bacteria $>$ denitrification by denitrifying bacteria $>\mathrm{SO}_{4}$ reduction by $\mathrm{SRB}\left(\mathrm{H}_{2} \mathrm{~S}\right.$ generation) [18]. Therefore, if 
dissolved $\mathrm{O}_{2}$ or $\mathrm{NO}_{3}$ exists, $\mathrm{SO}_{4}$ reduction hardly occurs.

If the $\mathrm{NO}_{3}$ addition method were applicable to the waste layer as well, that method would be a realistic $\mathrm{H}_{2} \mathrm{~S}$ generation suppression method at an actual landfill site. $\mathrm{NO}_{3}$ reagent is used in sewage systems [17]. Compost made from waste organic matter also contains $\mathrm{NO}_{3}[19,20]$. Therefore, if useless $\mathrm{NO}_{3}$ in the market could be used at landfill sites, low cost and effective use of resources would be accomplished.

The authors quantitatively estimated $\mathrm{H}_{2} \mathrm{~S}$ generation suppression by $\mathrm{NO}_{3}$ (reagent and compost-derived) addition [21]. The experiment was conducted on a beaker scale and in a complete mixing system. However, column percolation experiments are required to study the applicability of the $\mathrm{NO}_{3}$ addition method at an actual landfill site. In regard to the addition of compost-derived $\mathrm{NO}_{3}$, not only the injection of extract derived from compost into the waste layer, but also the utilization of rainfall infiltration through compost on top of the waste layer is assumed. Furthermore, as $\mathrm{NO}_{3}$ addition is an alternative method for supplying oxygen, $\mathrm{H}_{2} \mathrm{~S}$ generation suppression by $\mathrm{NO}_{3}$ addition should be compared with that by $\mathrm{O}_{2}$ supply.

In this study, $\mathrm{H}_{2} \mathrm{~S}$ generation suppression by the addition of $\mathrm{NO}_{3}$ from reagent and compost, and $\mathrm{O}_{2}$ supply was quantitatively estimated by conducting column percolation experiments.

\section{Materials and Methods}

\subsection{Outline of Experiments}

$\mathrm{H}_{2} \mathrm{~S}$ was generated in an airtight acrylic column, and $\mathrm{H}_{2} \mathrm{~S}$ generation suppression by $\mathrm{NO}_{3}$ or $\mathrm{O}_{2}$ addition was evaluated. Specifically, the column was filled with gypsum, organic matter solution was introduced from the top, and an anaerobic condition was preserved. Then, the reproducibility of $\mathrm{H}_{2} \mathrm{~S}_{\text {high }}$ generation was confirmed. $\mathrm{H}_{2} \mathrm{~S}$ in liquid and gas phases was removed by bubbling nitrogen $\left(\mathrm{N}_{2}\right)$ gas. $\mathrm{NO}_{3}$ or $\mathrm{O}_{2}$ was added into the column, and the concentration of re-generated $\mathrm{H}_{2} \mathrm{~S}$ was measured.

\subsection{Materials}

Table 1. Details of samples.

\begin{tabular}{|c|c|}
\hline Component & Product name, company, type \\
\hline $\begin{array}{l}\text { Organic } \\
\text { matter }\end{array}$ & $\begin{array}{l}\text { Dried Yeast Extract D-3, Wako Pure Chemical Industries } \\
\text { Lactose Broth DAIGO, Wako Pure Chemical Industries } \\
\text { (equivalently mixed) }\end{array}$ \\
\hline $\mathrm{SO}_{4}$ & Waste gypsum board (crushed into $<10 \mathrm{~mm}$ particles) \\
\hline Gravel & $<10 \mathrm{~mm}$, washed with water \\
\hline Nutrient & $\begin{array}{l}\text { BOD Nutrient Buffer Pillows for } 6 \text { L sample, APHA } \\
\text { Formulation, HACH COMPANY ( } 1 \text { pillow mixed with } 500 \\
\text { mL pure water) }\end{array}$ \\
\hline Seeding & $\begin{array}{l}\text { Black sediment in an ornamental pond ( } 3 \mathrm{~g} \text { mixed with } 500 \\
\text { mL pure water) }\end{array}$ \\
\hline $\begin{array}{l}\mathrm{NO}_{3} \\
\text { (reagent) }\end{array}$ & Sodium Nitrate, 1st grade, Wako Pure Chemical Industries \\
\hline $\begin{array}{l}\mathrm{NO}_{3} \\
\text { (compost) }\end{array}$ & Sewage sludge compost \\
\hline $\mathrm{O}_{2}$ & Aerated water or air bubbling \\
\hline
\end{tabular}

Details of the samples are shown in Table 1. Medium for microbial culture and waste gypsum board $\left(\mathrm{CaSO}_{4} \cdot 2 \mathrm{H}_{2} \mathrm{O}\right)$ were used as sources of organic matter and $\mathrm{SO}_{4}$, respectively. Sodium nitrate $\left(\mathrm{NaNO}_{3}\right)$ reagent and sewage sludge compost were used as sources of $\mathrm{NO}_{3}$, and air was used as the source of $\mathrm{O}_{2} . \mathrm{NO}_{3}$ content in the compost was $2.8 \mathrm{~g}-\mathrm{NO}_{3} / 100$ g-compost.

\subsection{Experimental Setup}

As shown in Figure 1, an airtight column was made by connecting the acrylic column $(10 \mathrm{~cm}$ inner diameter, $40 \mathrm{~cm}$ height, and $3.1 \mathrm{~L}$ inner volume) to a $100 \mathrm{~mL}$ plastic syringe. The syringe was filled with $50 \mathrm{~mL}$ of $\mathrm{N}_{2}$ gas. The column was filled with solid sample $(1.8 \mathrm{~kg}$ of a mixture of gypsum particles and gravel in 1:10 weight ratio; called waste layer hereafter). The height of the waste layer was $35 \mathrm{~cm}$. Then, $400 \mathrm{~mL}$ of a mixture of nutrient and seeding was added. Tap water was introduced to a height of $30 \mathrm{~cm}$. Four columns were prepared, i.e., columns for control, $\mathrm{NO}_{3}$ (reagent) addition, $\mathrm{NO}_{3}$ (compost) addition, and $\mathrm{O}_{2}$ addition. Hereafter, those columns are called control, NR, NC, and $\mathrm{OX}$, respectively.

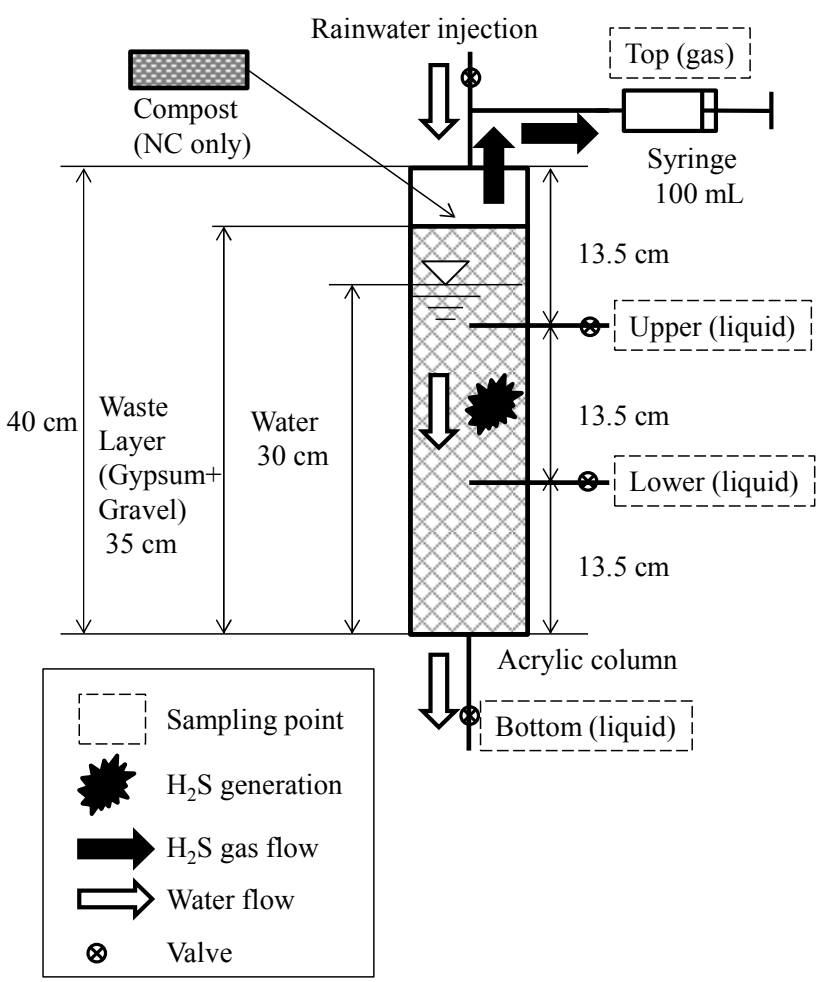

Figure 1. Schematic diagram of column.

\subsection{Experimental Methods}

At first, the stable generation of $\mathrm{H}_{2} \mathrm{~S}_{\text {high }}$ is necessary prior to the $\mathrm{H}_{2} \mathrm{~S}$ generation suppression experiment. The conditions for $\mathrm{H}_{2} \mathrm{~S}_{\text {high }}$ generation were as follows: maintenance of (1) an appropriate environment for SRB multiplication (anaerobic condition, temperature for mesophilic bacterial growth), (2) high concentration of organic matter, and (3) presence of $\mathrm{SO}_{4}$. 
To maintain condition (1), the column head space was filled with $\mathrm{N}_{2}$. Valves shown in Figure 1 were shut except for rainwater injection or sampling. Most of the waste layer was filled with rainwater, and the column was set in an incubator $\left(35^{\circ} \mathrm{C}\right)$. To maintain condition (2), organic matter was added to rainwater. To maintain condition (3), $\mathrm{SO}_{4}$ was introduced into the column in an amount equivalent to approximately 20 times that required for the saturation of $\mathrm{CaSO}_{4} \cdot 2 \mathrm{H}_{2} \mathrm{O}$ (approximately $1700 \mathrm{mg}-\mathrm{SO}_{4} / \mathrm{L}, 17.6 \mathrm{mmol}-\mathrm{SO}_{4} / \mathrm{L}$ [22]).

Assuming rainfall at an actual landfill site, artificial rainwater (tap water) was injected with a syringe from the top of the column once every three days. The injected volume was $110 \mathrm{~mL}$ every three days, which corresponded to the annual precipitation in Japan, i.e., approximately $1700 \mathrm{~mm} / \mathrm{y}$. Organic matter was added to the rainwater (13.6 g-C/L). $\mathrm{H}_{2} \mathrm{~S}$ in the liquid and gas phases was removed by bubbling $\mathrm{N}_{2}$ gas when $\mathrm{H}_{2} \mathrm{~S}_{\text {high }}$ was observed. $\mathrm{H}_{2} \mathrm{~S}_{\text {high }}$ observation and $\mathrm{H}_{2} \mathrm{~S}$ removal were conducted three times as the acclimation stage, and then, the $\mathrm{H}_{2} \mathrm{~S}$ generation suppression test was performed.

In $\mathrm{NR}, \mathrm{NO}_{3}$ reagent was added to the rainwater (19.05 g- $\mathrm{NaNO}_{3} / \mathrm{L}$ ). In $\mathrm{NC}$, the waste layer was overlaid with approximately $150 \mathrm{~g}$ of compost. $\mathrm{NO}_{3}$ in the compost was leached and transported to the waste layer by rainfall. The compost was replaced once every six days. In OX, two methods of $\mathrm{O}_{2}$ supply were adopted, i.e., rainwater was aerated to saturate $\mathrm{O}_{2}$, and air was directly bubbled from the bottom of the column. In air bubbling, air in an empty plastic bottle was introduced into the column by a closed system in order to prevent leakage of $\mathrm{H}_{2} \mathrm{~S}$ from the column (Figure 2).

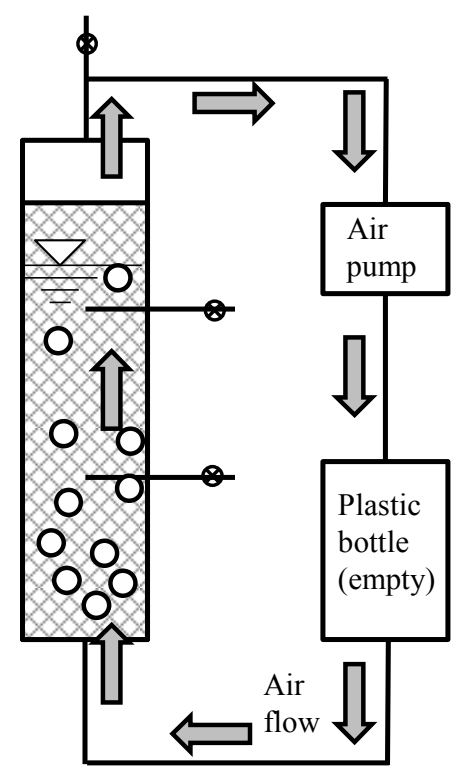

Figure 2. Schematic diagram of air bubbling $(O X)$.

\subsection{Analytical Procedure}

The objects of measurement were the gas and liquid phases in the column. Measurement items for the gas phase were $\mathrm{H}_{2} \mathrm{~S}$ concentration and gas volume. Measurement items for the liquid phase were $\mathrm{pH}$, electric conductivity (EC), ORP, dissolved oxygen (DO), TOC, $\mathrm{NO}_{3}$ concentration, and liquid volume. Sampling was conducted once every three days.

In regard to the gas phase, $\mathrm{H}_{2} \mathrm{~S}$ was measured with a portable gas detector for worker safety (XS-2200, controlled potential electrolysis, NEW COSMOS ELECTRIC CO., LTD.). Gas volume in the plastic syringe was measured by reading the scale of the syringe.

In regard to the liquid phase, HORIBA B-212 $(\mathrm{pH})$, HORIBA B-173 (EC), HORIBA-D-55 and 9300-10D (ORP), HORIBA-D-55 and 9520-10D (DO), Shimadzu TOC-V (TOC), and Thermo Fisher Scientific ICS - $1100\left(\mathrm{NO}_{3}\right)$ were used. Liquid volume was estimated by measuring the gross weight of the column. One hundred and ten milliliters of liquid was sampled from the liquid sampling points (Figure 1) with a plastic syringe. $\mathrm{H}_{2} \mathrm{~S}$ in the liquid phase was measured by head space sampling.

\section{Results}

The cumulative amounts of oxygen added $\left(\mathrm{O}\right.$ of $\mathrm{NO}_{3}$ or $\mathrm{O}_{2}$ ) are shown in Figure 3. The unit is $\mathrm{mmol}-\mathrm{O} / \mathrm{L}$, i.e., added oxygen/liquid volume in the column. The amount in NR was calculated from the amount of $\mathrm{NaNO}_{3}$ added. The amount in $\mathrm{NC}$ was determined by calculating the difference between the original amount of compost $\mathrm{NO}_{3}$ and the residual amount. The amount in OX was determined by calculating the difference of DO in water in the column between before and after aeration. The cumulative amounts of oxygen added exceeded $300 \mathrm{mmol}-\mathrm{O} / \mathrm{L}$ in NR and $\mathrm{NC}$ on day 75 , although it was only approximately $2 \mathrm{mmol}-\mathrm{O} / \mathrm{L}$ in OX.

Changes in $\mathrm{H}_{2} \mathrm{~S}$ concentration and ORP in control, $\mathrm{NR}, \mathrm{NC}$, and $\mathrm{OX}$ at the lower point of the column are shown in Figures 4 to 7 , respectively ( $*$ means $\mathrm{N}_{2}$ gas bubbling). $\mathrm{pH}$ ranged from 5.2 to 8.9, showed an increase with time, and was around 8 after 40 days. EC ranged from 2.7 to $14.8 \mathrm{mS} / \mathrm{cm}$, and was increased with time upon the addition of solution.

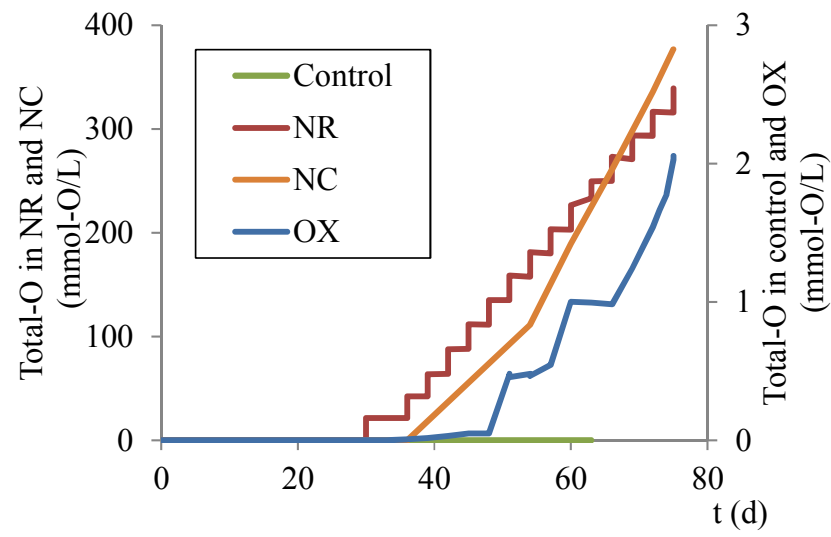

Figure 3. Cumulative amounts of oxygen added.

\subsection{Control}

ORP in control was below $-300 \mathrm{mV}$ (standard hydrogen electrode) after day 10 and $\mathrm{H}_{2} \mathrm{~S}_{\text {high }}$ was generated repeatedly (Figure 4). Thereafter, ORP was increased from approximately -500 to $-400 \mathrm{mV}$, although the reason was unknown. The average ORP after 50 days was $-356 \mathrm{mV} . \mathrm{H}_{2} \mathrm{~S}$ 
was rapidly regenerated after removal by bubbling $\mathrm{N}_{2}$ gas.

\subsection{NR: Nitrate (Reagent) Addition}

ORP in NR was increased upon the addition of $\mathrm{NO}_{3}$ (Figure 5). $\mathrm{H}_{2} \mathrm{~S}_{\text {high }}$ was generated and ORP was below $-200 \mathrm{mV}$ from day 30 to day 52. After day 52, ORP exceeded $-200 \mathrm{mV}$ three times and no $\mathrm{H}_{2} \mathrm{~S}_{\text {high }}$ was generated. The average ORP after 50 days was $-283 \mathrm{mV}$.

\subsection{NC: Nitrate (Compost) Addition}

ORP in NC was increased repeatedly upon the addition of compost (Figure 6). However, the average ORP after 50 days was $-316 \mathrm{mV}$, i.e., almost the same as that of control. $\mathrm{H}_{2} \mathrm{~S}_{\text {high }}$ was generated repeatedly.

\subsection{OX: Oxygen Addition}

ORP in OX was increased drastically upon the addition of oxygen (Figure 7 ). $\mathrm{H}_{2} \mathrm{~S}_{\text {high }}$ was generated repeatedly from day 36 to day 51 during which $\mathrm{O}_{2}$ was introduced by adding saturated water. However, the average ORP after 50 days was $-166 \mathrm{mV}$. Thereafter, $\mathrm{O}_{2}$ was added by air bubbling and $\mathrm{H}_{2} \mathrm{~S}$ generation was decreased.

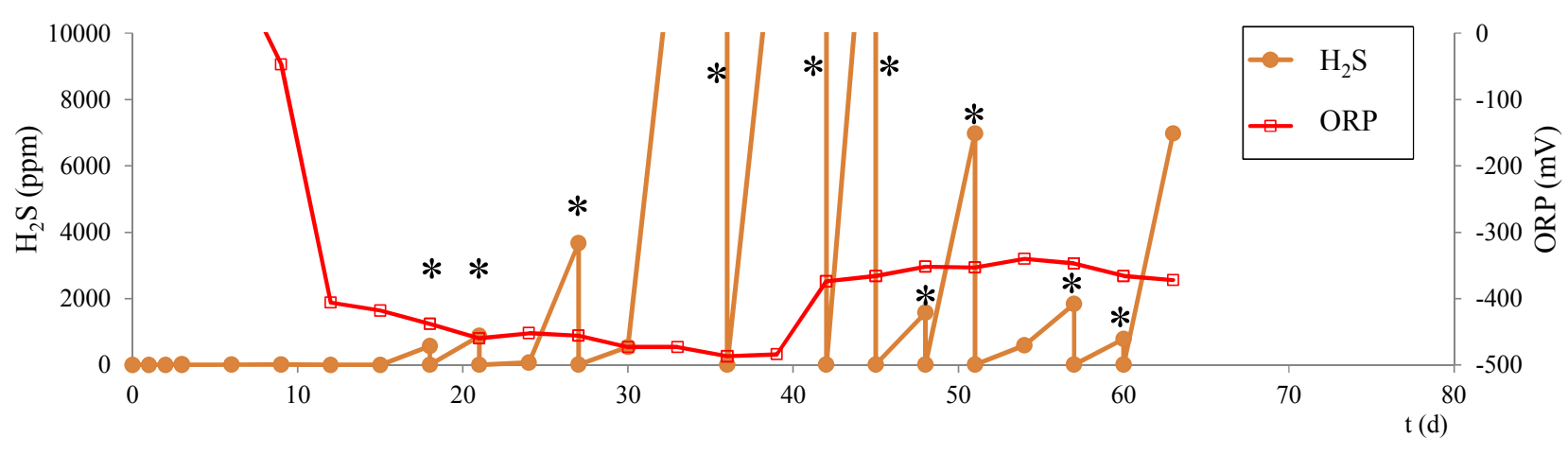

Figure 4. ORP and $\mathrm{H}_{2} \mathrm{~S}$ concentration changes in control.

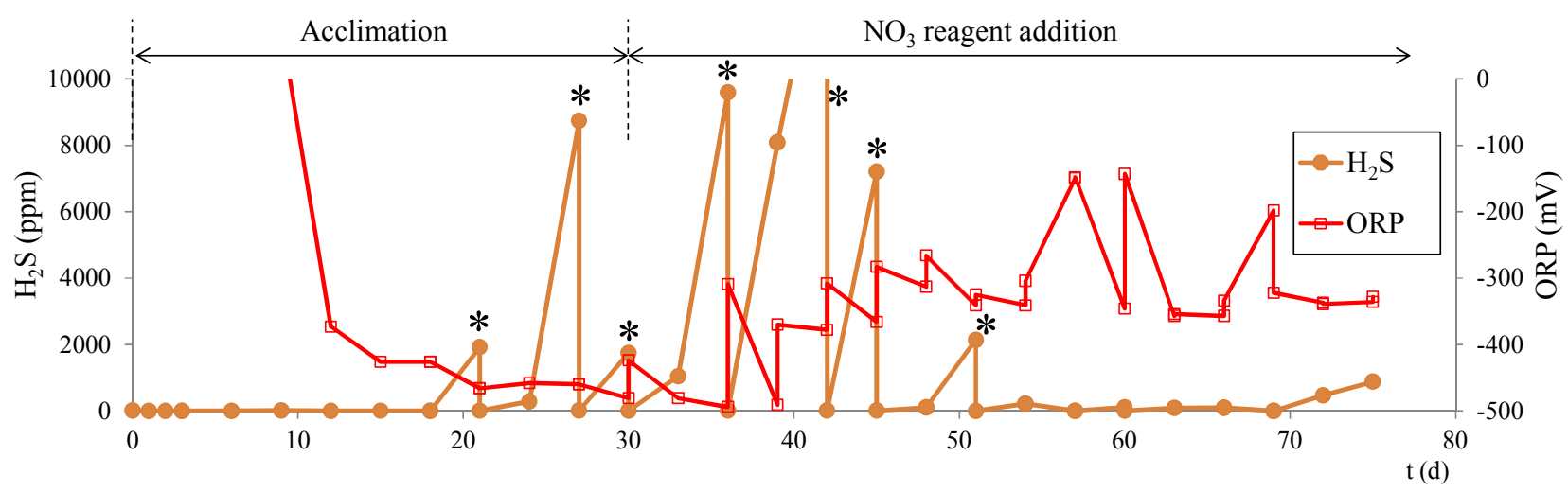

Figure 5. ORP and $\mathrm{H}_{2} \mathrm{~S}$ concentration changes in control.

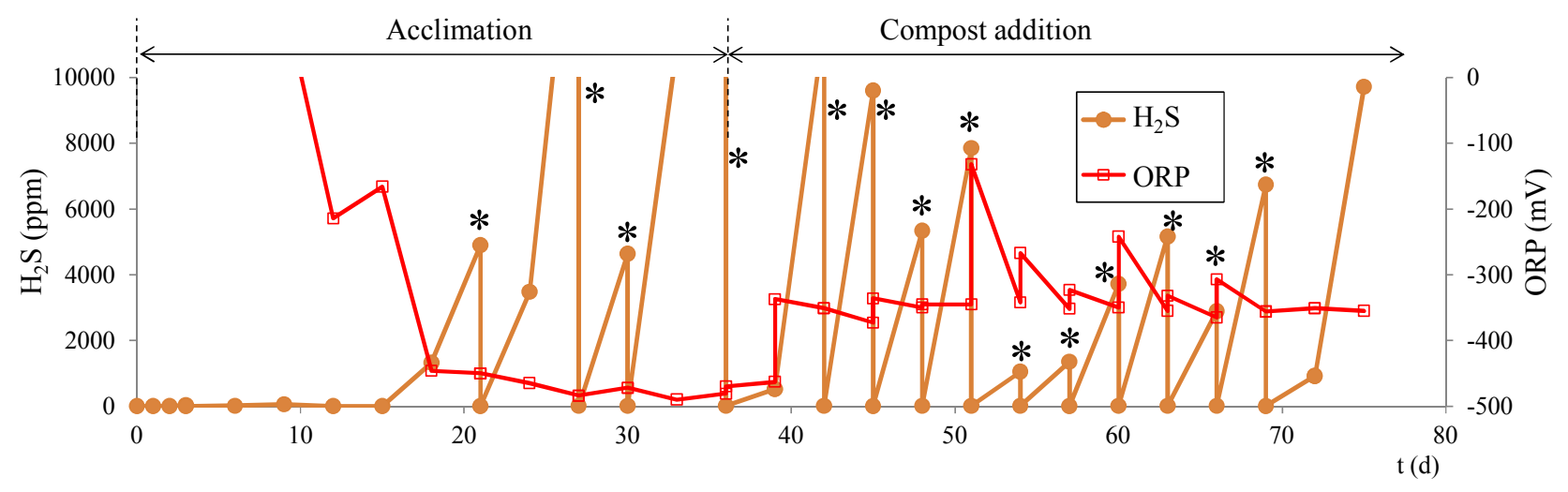

Figure 6. ORP and $\mathrm{H}_{2} \mathrm{~S}$ concentration changes in control. 


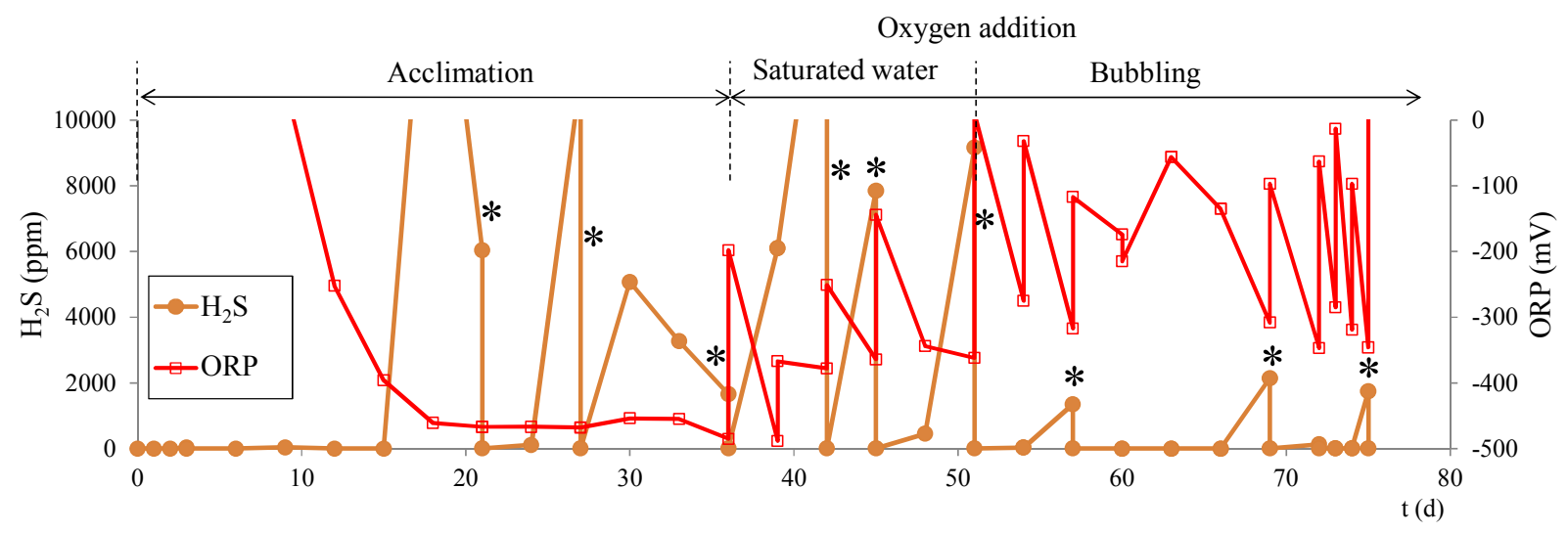

Figure 7. $\mathrm{ORP}$ and $\mathrm{H}_{2} \mathrm{~S}$ concentration changes in control.

\section{Discussion}

\subsection{Quantitative Evaluation of $\mathrm{H}_{2} \mathrm{~S}$ Generation Suppression}

The effects of $\mathrm{NO}_{3}$ or $\mathrm{O}_{2}$ addition on $\mathrm{H}_{2} \mathrm{~S}$ generation suppression were quantitatively estimated as follows. The cumulative amounts of $\mathrm{H}_{2} \mathrm{~S}$ generated are shown in Figure 8. The cumulative amount was determined from the total amount of $\mathrm{H}_{2} \mathrm{~S}$ in the column and the amount of $\mathrm{H}_{2} \mathrm{~S}$ removed by bubbling $\mathrm{N}_{2}$ gas. It is known that $\mathrm{H}_{2} \mathrm{~S}$ exists in not only the gas phase but also the liquid phase. Therefore, the total amount of $\mathrm{H}_{2} \mathrm{~S}$ in the column was equivalent to the amounts in the gas and liquid phases. However, only the concentration of $\mathrm{H}_{2} \mathrm{~S}$ in the gas phase was measured. Using the concentration in the gas phase (determined by taking the average of the concentrations measured at the top, upper, lower, and bottom parts of the column), gas volume, liquid volume, and $\mathrm{pH}$, concentration in the liquid phase was calculated according to Henry's law and an equilibrium relationship in the liquid phase [23]. As $\mathrm{H}_{2} \mathrm{~S}$ was generated from the liquid phase, the amount generated $\left(\mathrm{mmol}-\mathrm{H}_{2} \mathrm{~S}\right)$ was converted into the amount per unit liquid volume $\left(\mathrm{mmol}-\mathrm{H}_{2} \mathrm{~S} / \mathrm{L}\right)$. The cumulative amounts on day 60 in control, $\mathrm{NR}, \mathrm{NC}$, and $\mathrm{OX}$ were $69,26,71$, and $31 \mathrm{mmol}-\mathrm{H}_{2} \mathrm{~S} / \mathrm{L}$, respectively. The amounts in NR and OX were half that in control. However, the amount in $\mathrm{NC}$ was approximately the same as that in control. The effects of $\mathrm{H}_{2} \mathrm{~S}$ generation suppression were observed in NR after 45 days and in OX after 50 days. In NR, ORP exceeded $-200 \mathrm{mV}$ after 45 days and the suppression effect was observed. In OX, air bubbling was started after 50 days and the suppression effect was also observed. Therefore, the $\mathrm{H}_{2} \mathrm{~S}$ generation rates from days 50 to 60 were calculated. The generation rates in control, NR, $\mathrm{NC}$, and $\mathrm{OX}$ were $0.86,0.019,0.75$, and 0.041 mmol- $\mathrm{H}_{2} \mathrm{~S} /(\mathrm{L} \cdot \mathrm{d})$, respectively, and the rates in $\mathrm{NR}, \mathrm{NC}$, and $\mathrm{OX}$ were $0.02,0.9$, and 0.05 times that in control. In this way, the $\mathrm{H}_{2} \mathrm{~S}$ generation suppression effects of $\mathrm{NO}_{3}$ reagent addition were observed.

The purpose of this study was to estimate suppression effects not in a complete mixing system, but in column percolation experiments. $\mathrm{H}_{2} \mathrm{~S}$ concentration distributions in the height direction (median value from days 50 to 70) are shown in Figure 9. In NR, although $\mathrm{NO}_{3}$ was injected from the top of the column, $\mathrm{H}_{2} \mathrm{~S}$ concentrations at the lower and bottom parts of the column were not high compared with the top and upper parts, i.e., the suppression effect reached the deep layer. In NC, although no suppression effect was observed according to the cumulative amounts of $\mathrm{H}_{2} \mathrm{~S}$ generated mentioned above, $\mathrm{H}_{2} \mathrm{~S}$ concentrations at the top and upper parts were low $(<20 \mathrm{ppm})$, i.e., the suppression effect was observed in the shallow layer. In $\mathrm{OX}, \mathrm{H}_{2} \mathrm{~S}$ concentrations at all the sampling points were low $(<20 \mathrm{ppm})$. The reason was probably because $\mathrm{O}_{2}$ was supplied to all the column layers by injecting air from the bottom to the top.

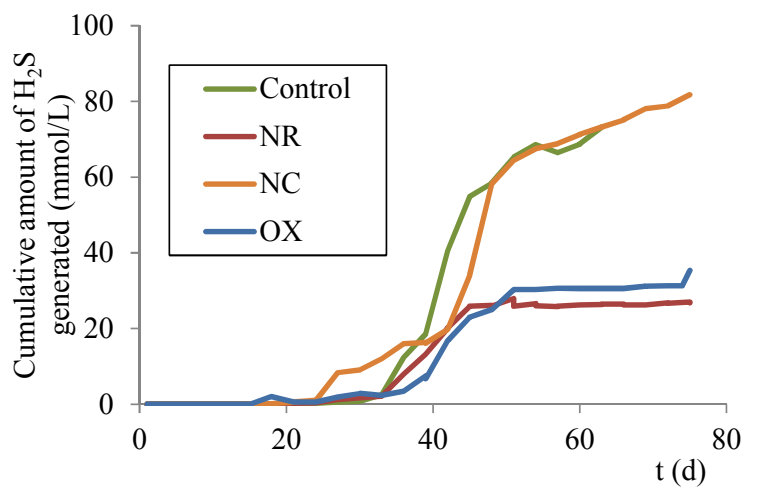

Figure 8. Cumulative amounts of $\mathrm{H}_{2} \mathrm{~S}$ generated.

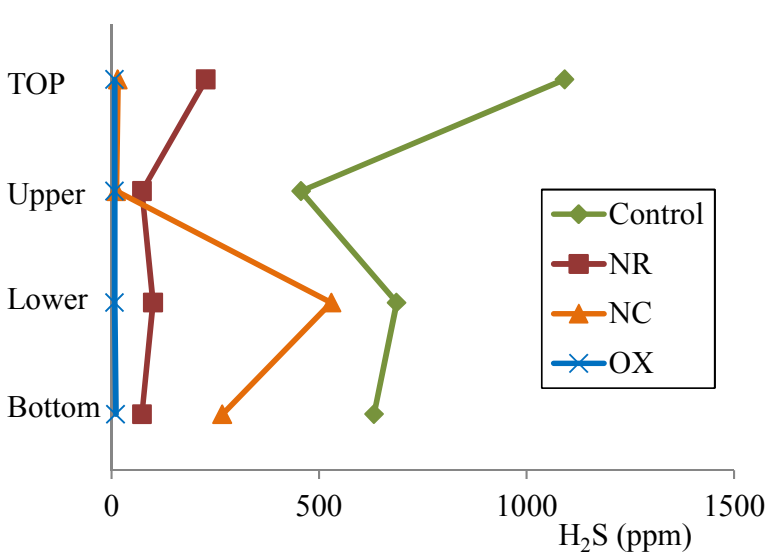

Figure 9. $\mathrm{H}_{2} \mathrm{~S}$ concentration distributions (median value from day 50 to day 70). 


\subsection{Problems Encountered, Application of Results, and Future Issues}

In this study, $\mathrm{H}_{2} \mathrm{~S}$ generation suppression effects were estimated not in a complete mixing system, but in column percolation experiments. In our previous investigation, as we could control $\mathrm{NO}_{3}$ concentration in the liquid phase in the complete mixing system, the relationship between $\mathrm{H}_{2} \mathrm{~S}$ generation suppression effect and $\mathrm{NO}_{3}$ concentration (reagent and compost-derived) could be expressed [21]. In this study, as the concentration of $\mathrm{H}_{2} \mathrm{~S}$ or $\mathrm{NO}_{3}$ varied with column depth, concentration control was difficult. Therefore, only the cumulative amounts of oxygen added and $\mathrm{H}_{2} \mathrm{~S}$ generated could be determined, and the suppression effects of $\mathrm{NO}_{3}$ or $\mathrm{O}_{2}$ addition were simply compared. Even though the amount of $\mathrm{O}_{2}$ added was much smaller than that of $\mathrm{NO}_{3}$ added, the suppression effect of $\mathrm{O}_{2}$ was as high as that of $\mathrm{NO}_{3}$. However, the suppression effect by injecting rainwater saturated with $\mathrm{O}_{2}$ was low. Assuming a closed system, such as the column percolation experiment used in this study, the whole prepared air could be introduced by bubbling into the system. However, an actual landfill site is an open system. Assuming that air is bubbled into the $\mathrm{H}_{2} \mathrm{~S}$ generating zone in the waste layer, it would take a long time to dissolve $\mathrm{O}_{2}$ in water and the air would diffuse out of the zone. Therefore, $\mathrm{O}_{2}$ injection is difficult. It is difficult to compare the suppression effects of $\mathrm{NO}_{3}$ and $\mathrm{O}_{2}$ while taking the ease of injection into consideration.

The amount of $\mathrm{NO}_{3}$ to be added to a waste layer of a landfill site where $\mathrm{H}_{2} \mathrm{~S}$ is generated could be estimated from the results of this study. Because the suppression effect of $\mathrm{NO}_{3}$ injection from the top of the waste layer reached not only the shallow layer but also the deep layer, it is suggested that the $\mathrm{NO}_{3}$ injection method from the top of the waste layer would be possible also at an actual landfill site. In other words, we could dispense with the $\mathrm{NO}_{3}$ injection method by introducing pipes deep into the waste layer.

Future issues are as follows. In regard to $\mathrm{NC}$, although the same amount of $\mathrm{NO}_{3}$ was added as in $\mathrm{NR}$, no suppression effect on the cumulative amount of $\mathrm{H}_{2} \mathrm{~S}$ generated was observed. Some substances contained in compost would hinder the suppression effect. Considering $\mathrm{NO}_{3}$ injection into an actual landfill site, the utilization of not $\mathrm{NO}_{3}$ reagent but useless $\mathrm{NO}_{3}$ in the market should be considered. Therefore, it is necessary to investigate factors hindering the suppression effect and the possibility of utilizing useless $\mathrm{NO}_{3}$ in the market, which has sufficient suppression effect. Environmental loading, such as eutrophication by application of the $\mathrm{NO}_{3}$ addition method at a pilot scale or an actual landfill site, and cost reduction by using useless $\mathrm{NO}_{3}$ in the market should be evaluated. As $\mathrm{NO}_{3}$ addition is an alternative method for supplying oxygen, its advantages should be evaluated quantitatively. The advantages include no consumption of large amounts of $\mathrm{NO}_{3}$ in the aerobic zone and consumption of organic matter by denitrification.

\section{Conclusion}

In this study, the $\mathrm{H}_{2} \mathrm{~S}$ generation suppression effects of $\mathrm{NO}_{3}$ addition using reagent (NR) and compost (NC), and $\mathrm{O}_{2}$ supply (OX) were quantitatively estimated in column percolation experiments.

The cumulative amounts of oxygen added exceeded 300 mmol-O/L in NR and NC, and approximately $2 \mathrm{mmol}-\mathrm{O} / \mathrm{L}$ in $\mathrm{OX}$ on day 75. The cumulative amounts of $\mathrm{H}_{2} \mathrm{~S}$ generated on day 60 in control, NR, NC, and OX were 69, 26, 71, and $31 \mathrm{mmol}-\mathrm{H}_{2} \mathrm{~S} / \mathrm{L}$, respectively. The amounts in NR and OX were half that in control. However, the amount in $\mathrm{NC}$ was approximately the same as that in control. $\mathrm{H}_{2} \mathrm{~S}$ generation rates from day 50 to day 60 in control, $\mathrm{NR}, \mathrm{NC}$, and $\mathrm{OX}$ were $0.86,0.019,0.75$, and $0.041 \mathrm{mmol}-\mathrm{H}_{2} \mathrm{~S} /(\mathrm{L} \cdot \mathrm{d})$, respectively, and the rates in $\mathrm{NR}, \mathrm{NC}$, and $\mathrm{OX}$ were 0.02 , 0.9 , and 0.05 times that in control. In this way, the $\mathrm{H}_{2} \mathrm{~S}$ generation suppression effects of $\mathrm{NO}_{3}$ reagent addition were observed. In NR, although $\mathrm{NO}_{3}$ was injected from the top of the column, the suppression effect reached the deep layer.

\section{Acknowledgement}

This research was supported by a Grant-in-Aid for Young Scientists B (25740039) from Japan Society for the Promotion of Science (JSPS).

\section{References}

[1] Lee, S., Xu, Q., Booth, M., Townsend, T.G., Chadik, P., Bitton, G., 2006. Reduced sulfur compounds in gas from construction and demolition debris landfills. Waste Management 26, 526-533.

[2] Eun, S., Reinhart, D.R., Cooper, C.D., Townsend, T.G., Faour, A., 2007. Hydrogen sulfide flux measurements from construction and demolition debris (C\&D) landfills. Waste Management 27, 220-227.

[3] Xu, Q., Townsend, T., Reinhart, D., 2010. Attenuation of hydrogen sulfide at construction and demolition debris landfills using alternative cover materials. Waste Management 30(4), 660-666.

[4] Fang, J.J., Yang, N., Cen, D.Y., Shao, L.M., He, P.J., 2012. Odor compounds from different sources of landfill: Characterization and source identification. Waste Management $32,1401-1410$.

[5] López, A., Lobo, A., 2014. Emissions of C\&D refuse in landfills: A European case. Waste Management 34, 1446-1454.

[6] Yue, E., Han, B., Sun, Y., Yang, T., 2014. Sulfide emissions from different areas of a municipal solid waste landfill in China. Waste Management 34, 1041-1044.

[7] Milby, T.H., Baselt, R.C., 1999. Hydrogen Sulfide Poisoning: Clarification of Some Controversial Issues. American Journal of Industrial Medicine 35, 192-195.

[8] Townsend, T., Tolaymat, T., Leo, K., Jambeck, J., 2004. Heavy metals in recovered fines from construction and demolition debris recycling facilities in Florida. Science of the Total Environment 332, 1-11. 
[9] Townsend, T., Jambeck, J., Jang, Y., Plaza, C., Xu, Q., Clark, C., 2005. C\&D Waste Landfill in Florida: Assessment of True Impact and Exploration of Innovative Control Techniques. Florida Center for Solid and Hazardous Waste Management, Gainesville, FL, USA.

[10] Jang, Y.C., Townsend, T., 2001. Sulfate leaching from recovered construction and demolition debris fines. Advances in Environmental Research 5(3), 203-217.

[11] Masamoto, H., Matsukiyo, A., Shigematsu, M., Matsufuji, Y., Yanase, R., 2012. Suppression of Hydrogen Sulfide Release from Waste Plasterboard Disposal in a Landfill-type Lysimeter. Journal of the Japan Society of Waste Management Experts 23(3), 144-153. (in Japanese)

[12] Naruoka, T., Ono, Y., 2004. Control measures against hydrogen sulfide production in final landfill sites. Journal of National Environmental Research 29(4), 14-19. (in Japanese)

[13] Bergersen, O., Haarstad, K., 2014. Treating landfill gas hydrogen sulphide with mineral wool waste (MWW) and rod mill waste (RMW). Waste Management 34, 141-147.

[14] Adib, F., Bagreev, A., Bandosz, T.J., 1999. Effect of Surface Characteristics of Wood-Based Activated Carbons on Adsorption of Hydrogen Sulfide. Journal of Colloid and Interface Science 214(2), 407-415.

[15] Karge, H.G., Raskó, J., 1978. Hydrogen sulfide adsorption on faujasite-type zeolites with systematically varied $\mathrm{Si}$-Al ratios. Journal of Colloid and Interface Science 64(3), 522-532.
[16] Bentzen, G., Smit, A.T., Bennett, D., Webster, N.J., Reinholt, F., Sletholt, E., Hobsont, J., 1995. Controlled dosing of nitrate for prevention of $\mathrm{H}_{2} \mathrm{~S}$ in a sewer network and the effects on the subsequent treatment processes. Water Science and Technology 31(7), 293-302.

[17] Zhang, L., Schryver, P.D., Gusseme, B.D., Muynck, W.D., Boon, N., Verstraete, W., 2008. Chemical and biological technologies for hydrogen sulfide emission control in sewer systems: A review. Water Research 42, 1-12.

[18] Stumm, W., Morgan, J.J., 1996. Aquatic chemistry -Third Edition, John Wiley \& Sons, New York.

[19] Farrell, M., Jones, D.L., 2010. Food waste composting: Its use as a peat replacement. Waste Management 30, 1495-1501.

[20] Hasan, K.M.M., Sarkar, G., Alamgir, M., Bari, Q.H., Haedrich, G., 2010. Study on the quality and stability of compost through a Demo Compost Plant. Waste Management 32, 2046-2055.

[21] Kitazaki, S., Xiao, K., Nakagawa, K., Kindaichi, T., Asakura. H., 2014. Hydrogen sulfide generation suppression by nitrate addition - application to solid waste landfill site. American Journal of Environmental Protection 3(5), 267-274.

[22] American Chemical Society, 2006. Reagent chemicals: specifications and procedures: American Chemical Society specifications, Oxford University Press. p. 242.

[23] Ono, Y., Tanaka, N., 2003. Preventing hazardous-level generation of hydrogen sulfide gas in landfill sites: Possibilities and administrative criteria. Journal of the Japan Society of Waste Management Experts 14(5), 248-257. (in Japanese). 